\title{
Československá liga proti antisemitismu
}

\author{
Jakub SEINER
}

\author{
ARTICLE INFO \\ Article history: \\ Received 28 February \\ 2019 \\ Accepted 1 April 2019 \\ Available online 31 \\ December 2019

\begin{tabular}{l}
\hline Keywords: \\
Anti-Semitism, \\
Czechoslovakia, Jews, \\
Associations, \\
Czechoslovak League \\
against Anti-Semitism \\
\hline J. Seiner \\
Národní pedagogické \\
muzeum a knihovna J. A. \\
Komenského $•$ \\
Valdštejnská $161 / 20$ \\
11800 Praha $1 \bullet$ \\
Česká republika • \\
seiner@npmk.cz
\end{tabular}

\begin{abstract}
Czechoslovak League against Anti-Semitism

This article is focused on the association of Czechoslovak League against Anti-Semitism. The first part of the atricle briefly mentions historical context of Czechoslovakia in period between the world wars and anti-semitic ideas existing in the first Czechoslovak Republic and relationship between Jewish society and social majority. The second part is focused mainly on activities of the association, how it tried to fight Anti-Semitism. The study is following up concreate steps of the association, like lectures, articles in journals, and the article analyzes which steps were the most effective. In the next part of the article is described how the Christian ideas and representatives influenced Czechoslovak League against Anti-Semitism. The paper also characterizes relations and positions between Jewish association in the Czechoslovakia and Czechoslovak League against Anti-Semitism.
\end{abstract}

\section{Úvod}

Československo představovalo v meziválečném období výspu demokracie ve střední Evropě. Republika se i přes velice obtížnou výchozí situaci nesnížila $\mathrm{k}$ zdánlivě jednodušším a efektivnějším formám vlády a po celé období své dvacetileté historie se ze všech sil pokoušela zachovat si svůj demokratický charakter. Demokratické instituce se snažily čelit vzrůstající radikalizaci Evropy zápasem proti sílícímu agresivnímu nacionalismu či rasistickým teoriím. Mezi organizace aktivně vystupující na obranu demokratických hodnot ve společnosti patřila také řada různých spolků. Následující př́spěvek se zabývá právě jedním $\mathrm{z}$ těchto spolků, jež se snažily přispět $\mathrm{k}$ potlačení vlivu totalitních idejí a myšlenek ve společnosti - Československou ligou proti antisemitismu. Tento článek si klade za cíl přiblížit spolkovou činnost, světonázor, v jehož duchu byl spolek veden, dále pak aktivity, které spolek realizoval. V první části článku je nastíněn širší historický rámec československé společnosti v meziválečném období, následující část je zaměřena na rekonstrukci a analýzu činnosti Československé ligy proti antisemitismu, s důrazem na podoby boje proti antisemitismu. 
K bohaté spolkové činnosti československé společnosti existuje odborná literatura (Křest’an, Blodigová a Bubeník, 2001, Laštovka et al., 1998 atp.), ovšem Československá liga proti antisemitismu stála doposud stranou badatelského zájmu. Autor této studie při zpracování tématu vycházel především $\mathrm{z}$ archivních pramenů $-\mathrm{z}$ fondů Spolkového katastru Archivu hlavního města Prahy, dále z fondu Zemský úřad Praha - Spolkové záležitosti, Národního archivu, dále z tiskovin vydaných Československou ligou proti antisemitismu, zejména z Věstníku spolku.

\section{Historický kontext - Postavení Židů v Československé republice}

Politická mapa se po první světové válce značně proměnila, na území starého kontinentu se objevila řada nových, tzv. nástupnických států, mezi nimiž také byla Československá republika. Československo vzniklo jako mnohonárodnostní stát, se silnými národnostními menšinami, jež se sideou nové republiky př́liš neztotožňovaly. ${ }^{1}$ Otázka národnostních menšin se ale týkala celé střední Evropy - stala se problémem celoevropským, a proto byla dohodovými mocnostmi zařazena do programu Versailleské mírové konference. Někteří představitelé dohodových mocností neúspěšně podporovali ochranu menšin jakožto nedílnou součást statutu Společnosti národů (Petráš, 2009, s. 31-35). V rámci národnostních menšin byla řešena také židovská otázka. Židé z československého území měli také na mírové konferenci svou politickou reprezentaci - Národní radu židovskou, která se snažila prosadit nejdůležitější stanoviska a na konferenci jednala i s československými zástupci (Čermáková, 2003, s. 10). Závěry Pařížské mírové konference byly obsaženy v mírové smlouvě podepsané se zástupci Československa 10. září 1919 v Saint-Germain-en-Laye, jež se také stala součástí československého právního řádu a byla vydána ve Sbírce zákonů a nařizení státu československého. V Hlavě I článku 2 smlouvy se uvádí: „Československo se zavazuje, že poskytne v̌̌em obyvateliom úplnou a naprostou ochranu jejich života a jejich svobody bez ohledu na jejich pưvod, státní občanství, rasu nebo náboženství. Všichni obyvatelé Československa budou míti právo volně vyznávati jak veřejně, tak soukromě jakékoli vyznání, náboženství nebo víru [...].“ (Sbírka zákonů a nařízení státu Československého, částka 134, 1921, s. 2305). V článku 8 se dále uvádí: „S přílušníky československými náležejícími k menšinám etnickým, náboženským neb jazykovým bude po právu a ve skutečnosti za stejných záruk zacházeno stejně jako s ostatními př́slušníky československými." (Sbírka zákonů a nařizení státu Československého, částka 134, 1921, s. 2307). Území Československé republiky pak bylo doplněno po podpisu Trianonské smlouvy s Mad'arskem v červnu roku 1920, kdy nové republice připadla oblast Podkarpatské Rusi (Bělina et al., 1995, s. 160). Na Versailleské mírové konferenci se otázka ochrany menšin a židovské menšiny prosadila i do jiných smluv s nástupnickými státy, nicméně pouze v Československu byla ujednání z ní plynoucí dodržována $\mathrm{v}$ praxi. Nařízení o ochraně národních, náboženských a rasových menšin byla obsažena také v Hlavě VI Ústavy Československé republiky z roku 1920 (s. 266). Ústava

\footnotetext{
${ }^{1}$ Zejména německé iredentistické hnutí, více např. BRÜGEL, Johann W., 2006. Češi a Němci 1918-1938. Praha: Academia, KURAL, Václav, 1993. Konflikt misto společenství, Češi a Němci v československém státě 1918 1938. Praha: ÚMV v naklad. R, ad.
} 
však záměrně nedefinuje jednotlivé národnostní menšiny, nicméně v prováděcích nařízeních při sčítání lidu byla jednou ze státem uznávaných národností i národnost židovská (Pěkný, 2001, s. 525). Židé si tedy mohli zvolit židovskou národnost i bez znalosti hebrejštiny či jidiš. V roce 1921 se k ní přihlásilo 180855 československých občanů (Sčítání lidu v republice Československé, 1934, s. 46). Celkový počet židovského obyvatelstva však byl ve skutečnosti vyšší, protože se Židé mohli přihlásit i k jakékoli jiné národnosti, což také často dělali důsledkem silného asimilačního hnutí. Nejsilnější asimilační hnutí bylo v Čechách, směrem na východ republiky pak sláblo a procentuálně nejvíce národních Židů se nacházelo na Podkarpatské Rusi (Čapková, 2013, s. 62-65).

Československo Židům skýtalo řadu možností pro společenský rozvoj - pokračovali $\mathrm{v}$ tradicích spolkové činnosti, která byla bohatá již v předválečném období, zapojovali se do politického života nové republiky, vznikaly židovské politické strany atp. Př́iznivé situaci pro židovskou populaci Československa napomáhal ve své podstatě vstřícný postoj československé společnosti k židovství. Politická reprezentace československého státu v čele s prezidentem T. G. Masarykem také většinově antisemitismus odmítala, přesto však při formování Československé republiky došlo k protižidovským excesům. Nejvýraznější antisemitské útoky se odehrály v počátečním období existence státu mezi lety 1918-1920, kdy výtržnosti přinesly i oběti na životech. Po skončení 1 . světové války se na území ČSR nacházela řada židovských uprchlíků z Haliče, jejichž př́itomnost jitřila české nacionalisty. Protižidovské výtržnosti se projevovaly v poválečných letech zejména rabováním židovských obchodů. Na protižidovskou náladu v československé společnosti měly také vliv mezinárodní události, antisemitské smýšlení posilovalo v souvislosti s postupem Rudé armády v Rusku. Stereotyp Žida-bolševika zde fungoval hlavně v agrárním tiskovém orgánu Venkov (Frank1 a Szabó, 2015, s. 261-263). Protižidovské smýšlení se projevovalo radikálněji na Slovensku, kde se angažovala $\mathrm{v}$ antisemitské kampani i část navrátivších se legionářů (Tamtéž, s. 269271). V českých zemích měly protižidovské bouře často zejména protiněmecké zabarvení. Události roku 1920 však měly spíše epizodní charakter, i když vypovídají o určité míře latentního antisemitismu ve společnosti a ochotě věnovat pozornost zažitým protižidovským stereotypům, které mohou ve vypjatých okamžicích přerůst v závažnější nepokoje. Př́ípadně mohl být antisemitismus způsoben i ekonomickými důvody, ty jsou rozpoznatelné také např́klad $\mathrm{v}$ předmluvě $\mathrm{M}$. J. Baláka, českého př́kladatele nechvalně proslulého antisemitského autora Augusta Rohlinga - Židé podle Talmudu: „Přes to všechno, že se židům u nás neubližuje, že s nimi žijeme co s občany stejných práv poživajícími, přes to všecko jsou titíž židé v Čechách, z českých mozolů zbohatnuvši v každém ohledu největšimi, nejzjevnějšimi nepřáteli národu českého, nejjizlivějšimi protivniky svaté naši věci národni!“" (Rohling, 1876, s. 4). Přesto se včeskoslovenské společnosti programový antisemitismus neuchytil. Československá politická a intelektuální elita antisemitismus striktně odmítala, pozdější předseda Československé ligy proti antisemitismu Emanuel Rádl označil antisemitismus za „ošklivý sen, který dusí naši víru ve vládu mravnosti, pravdy a ideálu ve světě (Křest'an, Blodigová a Bubeník, 2001, s. 22). Svým odmítavým postojem k antisemitismu byl známý i prezident T. G. Masaryk, mimo jiné prohlásil, že „dobrý křest’an nemůže být antisemitou“ 
(Friedmann, 1937, s. 10) a také „antisemitismus je podle mého soudu rána naše a vlastně jen naše, škodi nám, nás znemravňuje a zhrubuje“ (Tamtéž, s. 11).

Poněkud jiná situace panovala v německém a katolickém prostředí, kde byla míra latentního i otevřeného antisemitismu vyšší. Nejostřeji vyhraněná antisemitská politická strana Československa, která však zůstala po celé trvání první republiky marginální politickou silou, byla Slovanská strana protižidovská. Stranický program byl založen téměř výhradně na antisemitismu a odporu ke stávajícím pořádkům v československém státě. V pamfletu Proč byla založena Slovanská strana protižidovská je zřetelná silná inspirace z nechvalně proslulého antisemitského spisku Protokoly ze shromáždění sionských mudrců (Nilus, 1926) ${ }^{2}$, především co se týče hodnocení událostí v Rusku, ale také v dalších oblastech. Podobně argumentuje i Fedor Doubrava, který ve svém spise Tragédie Slovanstva a Francie vyzývá Slovany k rozhodnému boji proti Židům, zednářům a Němcům, nebot' podle něj jejich spojením došlo právě ke katastrofě v Rusku a bude docházet i nadále v jiných částech světa (1921). Slovanská strana protižidovská ve svém programovém prohlášení přináší svůj nacionalistický extrémně protižidovský postoj, přičemž zdůrazňuje křest’anské hodnoty a kritizuje stávající politickou konstelaci, nebot' se dle jejího mínění politici spojili se socialisty vedenými Židy, místo aby se domluvili s poctivými Čechy-lidovci (Proč byla založena Slovanská strana protižidovská v Praze? Pro blaho a spásu národa českého, 1921, s. 1). Slovanská strana protižidovská ve svém prohlášení přináší také řadu rozporných idejí. Strana dle své vlastní interpretace vědomě navazuje na myšlenky Karla Havličcka Borovského, Františka Palackého, Františka Ladislava Riegra, a dokonce J. A. Komenského ${ }^{3}$ (Tamtéž, s. 2), což jen poukazuje na obsahovou prázdnost stranické ideologie a vykazuje potřebu zaštítit se před veřejností významnými osobnostmi. Dále autor uvádí jako př́klad stranou hodný k následování myšlenky Josefa Velenovského, jenž mimo jiné pronesl: „Neurážejte city náboženské vyznavačů jakékoliv viry, jest barbarstvím káceti křrže, jako symboly mohamedánů a budhistư.“ (Tamtéž, s. 4). Silně antisemitská ideologie strany se skládala jak $\mathrm{z}$ rasového, tak protináboženského protižidovského zápalu, nicméně na dalších stranách brožury se můžeme dočíst následující tvrzení: „Slovanská strana protižidovská je tudiž jedinou nezájmovou, celonárodní čili netřídní nábožensky snášenlivou, a tudíž v pravém slova smyslu státní českou stranou." (Tamtéž s. 7). Zmiňovaná tolerantnost strany je v přímém rozporu se stranickým programem i s praxí ve stranickém periodickém tisku, nebot' vydávala od ledna roku 1920 svůj časopis Štít národa, na jehož stránkách se zřídkakdy objevily články s jinou než protižidovsky laděnou tematikou (Štít národa, 1920). I z prvního letmého pohledu na doplňující ilustrace k článkům je patrné, že předchozí výroky o snášenlivosti jsou pouze prázdné fráze, které absolutně nereflektují realitu.

Jak bylo výše uvedeno, také v německém prostředí se v některých oblastech antisemitismus více prosazoval, např́íklad na Německé univerzitě v Praze, kde měli silné zastoupení příznivci antisemitismu. Tato skutečnost se projevila např́iklad v roce 1922, kdy byl zvolen rektorem

\footnotetext{
${ }^{2}$ Česky vyšlo v letech 1926 a 1927.

${ }^{3}$ Postava Komenského je obzvláště zajímavá, nebot' se jí zaštit’ují jak zastánci antisemitismu, tak jeho odpůrci.
} 
pražské německé univerzity Samuel Steinherz ${ }^{4}$, což rozpoutalo mezi německými nacionalistickými studenty vlnu odporu (Křest’an, Blodigová a Bubeník, 2001, s. 23-25). Významné spolky jako např́klad Urania či Deutsches Haus nekladly v průběhu první republiky svým židovským členům při vstupu překážky. Situace se však radikálně změnila v polovině 30. let, kdy byli židovští členové označováni a postupně vyloučeni ze spolku. ${ }^{5}$

Nástup Adolfa Hitlera a nacistické strany v Německu k moci se začal záhy projevovat i v Československu v německé i židovské komunitě. Postupně se část německého prostředí radikalizovala a nacistická ideologie získávala stále větší okruh stoupenců, až nakonec převládla a zatlačila antifašistické a demokratické německé proudy v Československu. Do velké míry také situaci ovlivňovaly politické události a působení propagandy z Německa. Změny však nastaly i v samotné židovské komunitě. Nástup nacismu a posléze antisemitského zákonodárství znejistěl příznivce asimilačního hnutí, jež výrazně ve druhé polovině 30 . let oslabilo, a naopak posílil sionisty (Lichtwitz, 1937, s. 28-29). Řada spolků a hnutí také začala reagovat na sílící vlnu antisemitismu. V programech přednášek mnohých spolků se častěji objevují náměty spojené $\mathrm{s}$ antisemitismem a také jsou v rámci referátů akcentována humanistická témata. Právě sílící vliv antisemitismu ve společnosti dal vzniknout Československé lize proti antisemitismu, jež nebyla jediným spolkem, který by bojoval proti antisemitismu a šiŕil myšlenky humanismu. Téměř každý kulturní židovský spolek se s problematikou antisemitismu potýkal. Významnou organizaci šířící humanismus a zápasící s antisemitskými předsudky představoval řád B'nai B'rith. ${ }^{6}$ Široké působení řádu se zaměřovalo také na osvětovou činnost, např́klad plzeňská lóže pořádala př́ednášky o antisemitismu a o J. A. Komenském. ${ }^{7}$ Důležité je však zde poznamenat, že právě tyto aktivity byly jen pouhým zlomkem z širokého záběru činností, které organizace vykonávala.

\section{Československá liga proti antisemitismu}

V období první Československé republiky vznikla řada spolků a organizací, byla to tendence, která se prosazovala již v poslední třetině 19 . století a ve 20 . století i nadále pokračovala, i když ve 30. letech již se sníženou intenzitou. Úlohou spolků bylo organizování společenského, kulturního a také i politického života, jedním z nich byla Československá liga proti antisemitismu, jež vznikla v roce 1933 v Praze (Věstník Čsl. Ligy proti antisemitismu, 1936, I/3, s. 8) jako odbočka světového ústředí Ligue internationale contre l'antisémitisme v Paříži. ${ }^{8}$ Představovala nepolitickou a nadstranickou organizaci, sjednocující rozdílné

\footnotetext{
${ }^{4}$ Samuel Steinherz zahynul 16. 12. 1942 v Terezíně, pro více informací viz https://www.holocaust.cz/databazeobeti/obet/127127-samuel-steinherz/.

${ }^{5}$ Fond Deutsches Casino-Deutsches Haus. Karton 35, inv. číslo 634. Spolkový katastr, Archiv hl. m. Prahy, Praha.

${ }^{6}$ B'nai B'rith je dodnes existující mezinárodní humanistická židovská organizace, založená roku 1843 v New Yorku. V českých zemích působila již od roku 1893. Pro více informací viz https://www.bnaibrith.org/.

${ }^{7}$ Fond Velkolóže pro Československý stát X. nezávislého řádu B'nai B'rith. Karton č. 13, inv. č. 46. Národní archiv, Praha.

${ }^{8}$ Mezinárodní liga proti antisemitismu byla založena v Paříži v roce 1927 jako Ligue internationale contre les pogromes novinářem B. Lecachem. Impulsem pro její založení bylo zavraždění Simona Petljury v roce 1926 Samuelem Schwartzbardem v Paříži. Př́ičinou atentátu byla zodpovědnost S. Petljury za pogromy na Židy
} 
skupiny se společným cílem, kterým byl boj proti antisemitismu. Ve svých stanovách doslovně uvádí v paragrafu 2: „Účelem spolku jest sdružiti veškeré občany a občanky židovského vyznání nebo pưvodu, mající positivní vztah kžidovství a odhodlané hájiti svá existenční a kulturní práva proti antisemitismu, dále pak veškeré občany nežidovského pưvodu, ochotné spolupracovati se židovskými spoluobčany k hájení a udržení rovnoprávnosti židovských občanů v rámci platných zákonů “9 Spolek měl naplnit svůj účel přednáškami, schůzemi, veřejnými shromážděními, vydáváním tiskopisů, uměleckými akademiemi, výstavami, pořádáním sbírek a poskytováním bezplatné právní pomoci k tomu oprávněnými osobami. ${ }^{10}$ Za člena spolku mohl být přijat uchazeč židovského vyznání nebo původu a také každý občan Československé republiky odmítající zásady antisemitismu. Jednací řečí spolku, který sídlil v Praze (nejprve v Karlově ulici na Praze 1, v pozdějších letech v Revoluční třídě), byla čeština. Na ustavující schůzi valné hromady spolku ze 14. června 1933 byl zvolen výbor, který představovali: univerzitní prof. Emanuel Rádl ${ }^{11}$ (předseda), Dr. Karel Ludvík Reiner ${ }^{12}$ (místopředseda), redaktor z Prahy, Dr. Karel Galla ${ }^{13}$ (první zapisovatel), univerzitní docent, Eduard Taussig, úředník České banky Union v Praze, Viktor Kohn, ředitel, Zdeněk Münz, úředník České banky Union v Praze, Arnošt Freund, advokát, a Albert Roubíček, úřredník. ${ }^{14}$ Představitelé spolkového výboru byli lidé pohybující se v kulturním prostředí, které do velké míry spoluvytvářeli. Spolek představoval prostor pro setkávání jedinců s rozdílným světonázorem od radikálních sionistů přes stoupence asimilace až k nežidovským členům aktivním v křest’anských církvích. Každý rok se pořádala valná hromada spolku, na níž se rekapituloval uplynulý rok a proběhly také volby do vedení spolku a dalších funkcí. Brzy po ustanovení Ligy se na jejich přednáškách objevuje např́klad přední reprezentant politického života židovské komunity, dne 28. listopadu 1933 na spolkové schůzi vystoupil JUDr. Emil Margulies, ${ }^{15}$ významný představitel revizionistického kř́́dla sionismu, s vazbami na čelné představitele mezinárodního světového sionistického hnutí. ${ }^{16}$

První předseda spolku Emanuel Rádl, křest’anský filozof meziválečného období, byl znám svými názory odmítajícími nacionalismus a rasismus, již v roce 1918 publikoval spis Rassová theorie a národ, kde uvádí: „Každý necht má právo se k nám přidati, žid jako Turek, jen když poctivě uzná naše zákony!“ (Rádl, 1918, s. 24). Rádl považoval za princip jednotící národy

na Ukrajině v poválečném období. Za dva roky existence již sdružovala 6 tisíc lidí a přejmenovala se na Ligu proti antisemitismu. Ligue internationale contre l'antisémitisme se v roce 1979 přeměnila v International League against Racism and Anti-Semitism a je aktivní dodnes. Pro více informací viz článek 26 octobre 1927: Le procès Schwartzbard - Naissance d'un combat [online], [cit. 2018-09-15]. Dostupné z: http://archives.licra.org/26octobre-1927-le-proces-schwartzbard-naissance-dun-combat,http://licrachalons.free.fr/2005-09-

09_licra_jeunes_n_5.pdf; a také http://www.licra.org/qui-sommes-nous.

${ }^{9}$ Stanovy spolku Čsl. liga proti antisemitismu. Fond Zemský úřad Praha - spolkové záležitosti. Karton 984 , signatura 19a-3247-33, 3. Národní archiv, Praha.

10 Tamtéž.

${ }^{11}$ Emanuel Rádl byl přední český fillozof, také biolog, redaktor a předseda křest'anské organizace YMCA.

${ }^{12}$ Karel Ludvík Reiner byl významný redaktor listu Prager Presse.

${ }^{13}$ Karel Galla docent sociologie, po válce profesor pedagogiky na Masarykově univerzitě v Brně.

${ }^{14}$ Československá liga proti antisemitismu. Spolkový katastr. Karton 965, sign. XXII/2028. Archiv hl. m. Prahy, Praha.

15 JUDr. Emil Margulies, advokát z Litoměřic.

${ }^{16}$ Fond 531, Pozůstalost Dr. Emila Marguliese. Národní archiv, Praha. 
jejich společný cíl-ideu, z níž vychází program a jeho zásady-zákony. „Našimi bratřimi necht' jsou všichni lidé, kdo s námi věř v jednu pravdu a pracují o jejím uskutečnění, at' žijí kdekoli a mluví reči jakoukoli.“ (Tamtéž, s. 25). Nepopíral existenci rozdílů mezi lidmi - tvrdil, že „Odtud však ještě neplyne, že existuje jeden anatomický typ lidí, predurčený k nejvyšší inteligenci, zdroj vši civilisace, semeniště veškeré geniálnosti..." (Tamtéž, s. 7). Rasismus považoval za příznak nedemokratičnosti i v historii, způsobený potřebou legitimizovat vládu jedné skupiny nad druhou: „Účel rassových theorií je jest zrejejě agitační; jest to filosofie přizpůsobená pro dnešni válku, filosofie doporučujici nenávist $k$ druhým národům, omlouvající každou surovost, odučujicí úctě k civilisaci.“ (Tamtéž, s. 15). Humanistické ideály Emanuela Rádla vycházely z jeho hlubokého křest’anského přesvědčení. Řada dalších významných představitelů Československé ligy proti antisemitismu pocházela právě z křest’anských kruhů - mezi jinými vyniká např́klad farář Jednoty bratrské a pozdější předseda organizace Bohumil Vančura (Jednota bratrská, 2018). V průběhu roku 1933 přednášel na zasedáních spolku a od roku 1934 se pravidelně začal objevovat ve volených funkcích Ligy a $\mathrm{v}$ roce 1936 se stal jejím předsedou. ${ }^{17}$ Do ideologického rámce boje proti antisemitismu měly právě velmi blízko křest’anské myšlenky a ideály. Bohumil Vančura přednesl ve spolku např́klad přednášku na téma Co pojí křest'anský a židovský svět, vydal také článek se stejným názvem v rámci spolkového periodika (Věstník Čsl. Ligy proti antisemitismu, 1936, I/3, s. 1). Členy čestného výboru byli i další křest'anští představitelé, známý katolický spisovatel Dr. Silvestr Bratio, papežský komoří Dr. J. J. Rückel a významný představitel Jednoty bratrské Václav Vančura. ${ }^{18}$

Mezi další křest'anské stoupence Ligy proti antisemitismu patřil i Přemysl Pitter, významný pedagog, křest’anský humanista, sociální pracovník, stoupenec pacifistického hnutí a člověk se širokým okruhem působnosti (Matějček, 2017, s. 13). Společně se spisovatelkou Pavlou Moudrou, další členkou Ligy proti antisemitismu, vydávali od roku 1924 časopis Sbratření, v němž se snažili působit na širokou veřejnost $\mathrm{v}$ duchu křest’anských ideálů, do časopisu přispíval např́klad i Emanuel Rádl (Sbratření, 1931, roč. VII, č. 8, s. 2). Pavla Moudrá byla významná představitelka pacifistického hnutí a členka čestného výboru v Československé lize proti antisemitismu, ve spolku se aktivně podílela i na přednáškové činnosti. Např́klad dne 4. prosince 1935 pronesla přednášku v zimní zahradě Aschermannovy kavárny na téma Žena a muž ve vzájemném poměru ${ }^{19}$ a také přispívala články do Věstníku Ligy proti antisemitismu. Vztah Přemysla Pittra a Pavly Moudré nebyl pouze profesionální, kromě názorové blízkosti je pojilo také přátelství. P. Pitter jí v dopise z 5. května roku 1919 píše: „Jsem ještě mlád, ale zkusil jsem již ve světě mnoho. Jdu k Vám jako k matce, jako žáček. Vy zajisté mne povzbudíte na mé cestě a podpořite a poradite tam, kam moje zkušenost ještě nesahá. - Přikládám Vám

\footnotetext{
${ }^{17}$ Zpráva pro policejní ředitelství, Československá liga proti antisemitismu. Spolkový katastr. Karton 965, sign. XXII/2028. Archiv hl. m. Prahy, Praha.

${ }^{18}$ Václav Vančura se po válce v roce 1946 stal prvním biskupem obnovené Jednoty bratrské v Československu. Více viz http://www.jbcr.cz/index.php/jbpovalcecechy/353-vaclav-vancura.

${ }^{19}$ Československá liga proti antisemitismu. Spolkový katastr. Karton 965, sign. XXII/2028. Archiv hl. m. Prahy, Praha.
} 
veř̌e, jež jsou mou zpovědi a jež Vám věnuji. “20 Provázanost Přemysla Pittra a Pavly Moudré dokládá i Pittrův dopis z ledna 1938 adresovaný Lize, v němž se omlouvá za absenci na valné hromadě spolku (právě $\mathrm{z}$ důvodu účasti na oslavě narozenin paní $\mathrm{P}$. Moudré), dále mimo jiné píše: „Ujištuji Vás však svou naprostou sympatii ve Vaši snaze potírati bludy a zločiny rasové nenávisti a protižidovských pověr. Sám bojuji proti tomuto nepřiteli slovem i písmem po 17 let a také v našem časopise Sbratřeni velmi často prinášime zprávy a články, vychovávající a vyzbrojující čtenáre proti tomuto národnímu i světovému nebezpečí. “21 $\mathrm{Na}$ stránkách periodika Sbratření, jak Pitter zmiňuje, varoval například před šířením nebezpečných idejí při popisu své cesty po Německu z roku 1935: „Žádný národ nemůže se uzavřit duchovním vlivưm, které naň dorážejí ze sousedství. Také náš duchovní a veřejný život obráži velmi žretelně myšlenkové proudy, jež zmitaji světem. Velmi mocný je vliv jmenovitě z Německa. Proto mějme oči otevřeny a bedlivě zkoumejme. Zlé odmitejme, z dobrého se učme." (Sbratření, 1935, roč. XI, č. 5, s. 5). Přemysl Pitter ve své činnosti cílil zejména na péči o děti a mládež v jím vedeném Milíčově domě v Praze na Žižkově, kde děti mohly smysluplně trávit volný čas. P. Pitter se zde snažil se svými spolupracovníky dětem vštěpovat také zásady křest’anské morálky a humanismu. V pozdějších letech v průběhu druhé světové války, kdy do Milíčova domu ještě docházely židovské děti, dle vzpomínek pamětnice B. Sedláčkové dětem vysvětlil, proč musejí židovští kamarádi nosit na oděvu povinné označení: „Nosit žlutou hvězdu není žádná potupa. Ba právě naopak, jestliže pak víte, děti, že i Ježiš Kristus byl Žid. Narodil se vžidovské zemi Palestině a i jeho první učedníci byli Židé... Co můžeme v této době dělat my, děti? Musíme se snažit napravovat křivdy a pomáhat těm, kterým se dnes děje křivda." (Sedláčková, 1994, s. 47).

Ligou zastávané univerzální hodnoty měly blízko ke křest’anskému náboženství - není tak náhodou, že řada členů spolku patřila $\mathrm{k}$ významným představitelům křest'anského života. Křest'anský vliv na spolek může ukazovat i fakt, že v pozměněných spolkových stanovách z roku 1937 se poněkud upravilo znění účelu spolku. V paragrafu 2 Stanov se uvádí: „Účelem spolku jest sdružiti československé občany a občanky... zvláště proti škodlivým vliviom antijudaismu ${ }^{22}$ a rasismu. “23 V roce 1938 zaznamenali představitelé Ligy menší zájem o dění v organizaci z řad židovského členstva i židovské veřejnosti (Věstník Čsl. Ligy proti antisemitismu, 1938, III/1, s. 2). Otázkou zůstává, co způsobilo nezájem židovských spoluobčanů o spolkové aktivity, roli zde hrálo nejspíše více faktorů. Již v roce 1936 byl otištěn článek ve Věstníku Ligy o odmítání filosemitismu částí židovské populace: „Někdy se mi zdá, že židé jsou vůči filosemitismu háklivější než vi̊či antisemitismu... Jedni snad proto, že jsou k svému židovství dokonale lhostejni a sami sobě zapírají, že něco jsou... Druzí snad proto, že jsou př́liš hrdi a uzavření (Věstník Čsl. Ligy proti antisemitismu, 1936, I/5, s. 4).

Československá liga proti antisemitismu si hledala svou pozici mezi ostatními židovskými spolky. Jak bylo již výše zmíněno, v meziválečném období se musely všechny židovské

\footnotetext{
${ }^{20}$ Osobní korespondence. Karton 15a, inv.č. 832_2, ČAPP. Archiv Přemysla Pittra a Olgy Fierzové, Praha.

${ }^{21}$ Institucionální korespondence. Karton 16, ČAPP. Archiv Přemysla Pittra a Olgy Fierzové, Praha.

${ }^{22}$ Antijudaismus je typičtější výraz používaný v souvislosti s náboženstvím, není založen na principu rasy.

${ }^{23}$ Fond Zemský úřad Praha - spolkové záležitosti. Karton 1142, signatura 19-3297-1933, s. 1. Národní archiv, Praha.
} 
spolky vypořádat s narůstajícím významem antisemitismu. A Liga byla občas nucena obhájiti svoji existenci, některé židovské kruhy se ke spolku vyjadřovaly kriticky: „Vyslovuje se naivni obava, že Liga konkuruje některým židovským organizacím, jako by byla spolkem neb stranou židovskou. Skoro každá židovská organizace si o sobě myslí, že sama stači na boj proti antisemitismu, protože její program je jedině možné řěsení židovské otázky, a tudiž i poměru k ostatnímu světu." (Věstník Čsl. Ligy proti antisemitismu, 1936, I/ 9-10, s. 1-2). Právě takový dogmatismus Liga odmítala, neměla ambice vměšovat se do politických sporů jednotlivých židovských frakcí a upřednostňovala snahu oslovit co největší počet stoupenců všech ras, vyznání a přsvědčení. I přes občasné obtíže spolupracovala Liga proti antisemitismu s dalšími československými židovskými organizacemi a spolky. Např́íklad Svaz Čechů-židů pozval zástupce Ligy Bohumila Vančuru na svůj sjezd, kde mimo jiné pronesl: „Dovolte, abych vyslovil Vašemu sjezdu a Vaši pilné práci vřelý pozdrav Československé ligy proti antisemitismu. Děkujeme za pozvání... mnozi naši stoupenci ho použili včera $i$ dnes a ostatně jsou mnozí i členy Vašeho svazu. Liga proti antisemitismu po některých počátečních nesnázich se dopracovává určitého vymezení svých úkoli̊ a metod. Její jméno snad nezní uchu libozvučně, ale to její dvoji ,anti-proti 'tají v sobě velmi kladné ,pro' a my bychom rádi takové ušlechtilé a lidské pro zachytili intensivně a bez jakéhokoliv zúžení stranického a národnostního. Je to přece idea, vyznačená vznešenými odkazy náboženství starozákonního $i$ křestanského a vytčená opět v reformaci, ozývá se v Komenském i Masarykovi a vi̊bec v ideálu moderní demokracie." (Věstník Čsl. Ligy proti antisemitismu, 1936, I/1, s. 8). Stejně tak se účastnil O. Stross, delegát Svazu Čechů-židů, valné hromady Čsl. ligy. ${ }^{24}$ Čechožidé odmítli požadavky mladého křídla organizace na důraznější protiantisemitské zaměření spolkových činností s poukazem na existenci Čsl. Ligy proti antisemitismu a jejích spolkových aktivit.

Otázkou zůstává, zda tolik důvěřovali ve schopnosti Československé ligy proti antisemitismu, či se vedení Svazu Čechů-židů alibisticky snažilo nadnesenou otázku smést ze stolu. Nebot' slovy V. Lederera se českožidovský spolek ,nemůže a nesmí přizpůsobiti názorům pražské ulice a nesmíme sdileti strach židovských panikář̉ z pražských kaváren“ (Čapková, 2013, s. 201).

Zajímavé je pozorovat protichůdná stanoviska bojovníků proti antisemitismu a stoupenců antisemitských myšlenek, kterak se oba proudy zaštit’ují týmiž ideály, osobnostmi a mysliteli. Československá liga proti antisemitismu pořádala přednášky o vztahu Masaryka k Židům a také se na počest výročí prezidentových 85. narozenin konala dne 6. března 1935 Slavnostní valná hromada spolku. ${ }^{25}$ Zástupci Československé ligy proti antisemitismu se pokoušeli dokonce získat audienci u prezidenta republiky Edvarda Beneše. I přes kladné hodnocení organizace Čsl. ligy proti antisemitismu a jejího vztahu k Československu Policejní ředitelství nedoporučilo audienci uskutečnit - důvody, proč v reakci na dotaz Prezidentské kanceláře

\footnotetext{
${ }^{24}$ Fond Zemský úřad Praha - spolkové záležitosti. Karton 1142, signatura 19-3297-1933, 7. Národní archiv, Praha.

${ }_{25}$ Československá liga proti antisemitismu. Spolkový katastr. Karton 965, sign. XXII/2028. Archiv hl. m. Prahy, Praha.
} 
na stanovisko nedoporučilo Policejní ředitelství audienci realizovat, jsou zajímavé. Zamítavé stanovisko zohledňovalo mezinárodní situaci, nebot' jak se uvádí v policejní zprávě, o této audienci by se zajisté zmínil tiskový orgán Ligy, v němž jsou uveřejňovány kritické články vůči sousednímu Německu, a z výše uvedeného důvodu by zpráva o audienci u prezidenta mohla působit komplikace. ${ }^{26}$ Policejní ředitelství monitorovalo obecně spolkovou činnost a jednotlivé aktivity spolků musely být policejním orgánům nahlašovány a jimi schváleny. Stávalo se, že spolkové aktivity byly policií cenzurovány. Liga proti antisemitismu např́iklad plánovala uspořádat dne 28. 11. 1934 přednášku rabína Dr. Abrahama z Berlína na téma $C o$ jsem zažil $v$ Německu, policejní ředitelství ale přednášku zakázalo a zdůvodnilo ji podobným způsobem jako při nedoporučení audience: ,za nynější politické situace hrozí nebezpečí, že tímto shromážděním bude porušena veřejná bezpečnost a ohroženo obecné blaho.“27 Přednáška se nakonec uskutečnila pod změněným názvem Mé zkušenosti a cesta $k$ židovské jednotě 28 o 14 dní později.

Přednášková činnost patřila $\mathrm{k}$ jedné z hlavních aktivit spolku. Přednášky se pořádaly v sálech kaváren a byly určeny pro širokou veřejnost, dokonce se doporučovalo, aby členové spolku pozvali na přednášku své nežidovské známé. Na přednáškách vystupovali s referáty jak členové Ligy - častým řečníkem byl např́klad B. Vančura, tak i zahraniční hosté. ${ }^{29}$ Prostřednictvím přednášek se spolek snažil vyvracet ve společnosti mýty a předsudky o Židech, přinášet aktuální informace ze světa ohledně politických událostí, židovské problematiky. ${ }^{30}$ Přednášková činnost započala téměř okamžitě po ustanovení spolku, přednášky se nekonaly pravidelně, většinou však několikrát do měsíce. Neméně důležitým počinem Ligy byla vydavatelská činnost - od roku 1936 představoval Věstník Čsl. ligy důležité periodikum, vycházel měsíčně. $\mathrm{Na}$ jeho stránkách byli čtenáři informováni o nastávajících spolkových událostech, přednáškách, schůzích, vydavatelské činnosti spolku a také o dalších tématech, které korespondovaly se zaměřením spolku. Často také byly na stránkách Věstníku uveřejňovány části přednášek pořádaných Ligou. Analýzou příspěvků ve Věstníku a z obsahu přednášek lze určit tři tematické okruhy, na které se tvorba zaměřovala - jednalo se o vztah křest'anství a judaismu, potažmo křest’anů a Židů, dále pak o antisemitismus a židovské záležitosti, třetí okruh představovaly obecné humanistické principy a ideály, filozofické a etické otázky. Prostřednictvím těchto tematických článků se představitelé Ligy snažili porazit antisemitskou ideologii. Výše uvedené aktivity představují stěžejní činnost spolku, jejichž společným cílem bylo šíření těchto myšlenek mezi co nejširší okruh obyvatelstva. Šířením humanistických ideálů a vzděláváním společnosti chtěl spolek bojovat proti antisemitismu, redakce Věstníku ve svém úvodníku uvedla: „Věstník se stal

\footnotetext{
${ }^{26}$ Tamtéž.

${ }^{27}$ Tamtéž.

${ }^{28}$ Tamtéž.

${ }^{29}$ Tamtéž.

${ }^{30}$ Mezi lety 1934-1938 pořádala Liga například následující přednášky: R. J. Vonka - Židovství v kritice české reformace, Walter Tschuppik - Perspektivy antisemitismu, B. Vančura - Co pojí křestanský a židovský svět, P. Moudrá - Žena a muž ve vzájemném poměru, F. Bednář - Nové židovské zákonodárství v Německu, C. Hagar Antisemitismus a demokracie, G. Sicher - Maimonida, ad. Viz Československá liga proti antisemitismu. Spolkový katastr. Archiv hl. m. Prahy.
} 
instruktorem a buditelem [...] listem, jenž by probouzel svědomí a rozum i touhu po vyhlazení nakažlivin antijudaistických a rasových. Zároveň však i podával instruktivní pomoc všem upř́mným, kteři se chtěji odvážně utkati s nevědomostí nebo demagogii a potřebují myšlenkové výzbroje, di̊kazů a dokladů." (Věstník Čsl. Ligy proti antisemitismu, 1937, II/1, s. 2). Ve Věstníku se dále uvádí: „Antisemitismus vyrůstá z neznalosti. Lidé, kteři poznali podstatu židovského náboženství a židovské filozofie a ethiky, nemohou bez přetvářky zůstati $v$ temnu protižidovském. Ale je třeba hlasitě ř́ci: U nás je málo lidí, kteři by židovství a židy znali.“ (Věstník Čsl. Ligy proti antisemitismu, 1937, II/1, s. 2). Vzdělávání společnosti probíhalo v několika rovinách: otevřeně se polemizovalo s antisemitskými výmysly, vyvracely se stereotypy a nesmyslné výroky. V druhé rovině se naopak informovalo o judaismu a o Židech, aby neznalost ve společnosti neusnadňovala šíření antisemitských předpojatostí. A nakonec byli lidé seznamováni prostřednictvím křest’anství s obecně platnými hodnotami, přičemž byly vyhledávány a připomínány styčné body mezi oběma náboženstvími.

Spolek byl financován zejména prostřednictvím členských příspěvků a sbírek. ${ }^{31}$ Členský př́spěvek na rok 12 Kč i předplatné Věstníku 10 Kč byly stanoveny dle samotného vyjádření představitelů Ligy velmi nízko, aby si nejširší společenské vrstvy mohly dovolit vstup do spolku i předplatné Věstníku (Věstník Čsl. Ligy proti antisemitismu, 1937, II/1, s. 6). Pro srovnání - měsíční plat dělníka v roce 1932 představoval 342 Kč měsíčně a učitelé obecných škol pobírali ve trricátých letech v průměru 750-2250 Kč (Kárník, 2003, s. 37-40). Ačkoliv byla jednacím jazykem spolku čeština, tiskoviny včetně Věstníku byly také vydávány v německém jazyce, někdy i v mad’arském (Věstník Čsl. Ligy proti antisemitismu, 1936, I/5, s. 8). Stejně tak i Věstník vycházel v německém jazyce pod názvem Mitteilungen der Čsl. Liga gegen Antisemitismus (Věstník Čsl. Ligy proti antisemitismu, 1936, I/8, s. 7).

Měsíčník však nepředstavoval jediné vydavatelské působení spolku. Liga vydávala také informační brožury, které financovala z tiskového fondu. Z dostupných materiálů vyplývá, že jedním z největších problémů spolku představovalo financování jeho aktivit. Dá se tak usoudit z velice častých výzev o zaplacení členských poplatků a nedoplatků z minulých období, stejně jako výzvy k podpoře tiskového fondu uveřejňovaných ve Věstníku spolku (Věstník Čsl. Ligy proti antisemitismu, 1937, II/1, s. 4). Spolek svým nákladem kromě Věstníku vydal pouhé dvě publikace - brožuru Před zraky národi̊, vyšla ve třech jazykových mutacích - česky, německy a mad'arsky, a publikaci Židé mezi námi. ${ }^{32}$ Pozornost Československé ligy proti antisemitismu velice upoutal zoufalý čin židovského intelektuála původem ze Slovenska Stefana Luxe, jenž se na zasedání Společnosti národů v Ženevě zastřelil př́ímo v sále, kde zasedali diplomaté. Učinil tak z přesvědčení, že je nutné vyburcovat světové politiky z letargie, s níž pohlíží na situaci Židů v nacistickém Německu, na probíhající válečné konflikty a na postupně se blížící katastrofu způsobenou agresivní politikou Německa a Itálie

\footnotetext{
${ }^{31}$ Československá liga proti antisemitismu. Spolkový katastr. Karton 965, sign. XXII/2028. Archiv hl. m. Prahy, Praha.

${ }^{32}$ HAHN, Arnold, 1936. Před zraky národů, Proč umřel Stefan Lux? Jeho život, čin a poslední dopisy. Praha: nákladem ČSL. Ligy proti antisemitismu; VANČURA, Bohuslav, 1937. Židé mezi námi, rozhovor z našich dnů. Praha.
} 
(Hahn, 1936, s. 11). Liga proti antisemitismu pořádala o Stefanu Luxovi a jeho činu přednášky, byl mu věnován prostor i ve Věstníku Ligy (Věstník Čsl. Ligy proti antisemitismu, 1936, I/8). Obět', jakou S. Lux přinesl, nedosáhla však v celosvětovém měřítku př́ilišné pozornosti a i někteří autoři článků uveřejněných ve Věstníku Ligy považovali jeho čin za zbytečný.

O možných finančních těžkostech spolku a jeho nedostatečnému personálnímu zajištění může svědčit také fakt, že redakce kvůli práci na brožuře Před zraky národů nestihla vydat včas měsíčník, a proto bylo publikováno až dvojčíslo záŕí-ř́íjen. Dále při zasedání valné hromady v roce 1937 navrhoval pokladník spolku p. Max Kohner, „aby valná hromada uložila předsednictvu Ligy postarat se o získáni 500 mecenášů, kteři by ročním příspěvkem aspoň Kč 100 - zajistili spolku finančni basi“ ${ }^{33}$ Spolek vydával doporučení pro své členy, jakým způsobem mohou přispět k činnosti Ligy. Př́íslušníci spolku měli monitorovat veřejný prostor, pokud by se jim dostal do rukou nějaký rasistický či antisemitský materiál, měli vše oznámit Lize. Samozřjejmě si členové měli také předplácet Věstník a objednávat publikace vydané Ligou a každý člen se také měl snažit rozššríit řady spolku o nové stoupence (Věstník Čsl. Ligy proti antisemitismu, 1936, I/11-12, s. 8).

Spolek se brzy začal rozšiřrovat do dalších československých měst, již roku 1934 se rozšíril o pobočku v Brně a později i v Bratislavě. Roku 1935 spolek Československá liga proti antisemitismu čítal celkem 1905 členů. Nejvýznamnější pobočka spolku se nacházela v Praze - 1005 členů, brněnská filiálka měla 800 členů a nejméně početná byla organizace bratislavská se stovkou členů. ${ }^{34}$ Aktivní činnost vyvíjela také brněnská pobočka, zejména za předsednictví prof. Dr. M. Ryšánka. Liga měla vlastní sekretariát v Brně a dopisovatele v Olomouci, Moravské Ostravě, Uherském Brodě, Znojmě, Šumperku, Lipníku ad. Počet členů tedy neustále rostl, zejména na venkově (Věstník Čsl. Ligy proti antisemitismu, 1936, $\mathrm{I} / 8$, s. 8). V roce 1936 se pořádaly v moravských městech úspěšné propagační akce Ligy. Pobočka v Bratislavě poněkud stagnovala a nějaký čas se nacházela v krizi.

Liga proti antisemitismu nezaměřovala svoji činnost výhradně na osvětu, snažila se svým členům pomáhat i v jiných oblastech. Nemajetní členové Ligy mohli využívat bezplatné právní či lékařské poradny vedené taktéž členy spolku (Věstník Čsl. Ligy proti antisemitismu, 1936, I/4, s. 8). Liga se také snažila podporovat nezaměstnané mladé Židy, např́klad na svých stránkách ve Věstníku informovala: „Hlaste nám volná místa a pracovní přiležitosti. Židovští hoši a divky z Podkarpatské Rusi, nejchudšiho kraje naší republiky, zřídili si v Praze pracovní souručenství. Přijmou každou práci, zejména manuelní. Umožniti jim skrovné živobytí jest př́kazem lidskosti.“ (Věstník Čsl. Ligy proti antisemitismu, 1936, I/4, s. 8). V druhé polovině 30. let se také spolek orientoval na pomoc emigrantům z Německa. V některých př́padech Liga zasáhla u adekvátních úřadů, aby dosáhla nápravy, např́klad když se jednalo o šíření ilegálních brožur s antisemitským obsahem „Něco pravdy o zednářích“ (Věstník Čsl. Ligy proti antisemitismu, 1936, I/11-12, s. 7).

\footnotetext{
${ }^{33}$ Fond Zemský úřad Praha - spolkové záležitosti. Karton 1142, signatura 19-3297-1933. Národní archiv, Praha.

${ }^{34}$ Československá liga proti antisemitismu. Spolkový katastr. Karton 965, sign. XXII/2028. Archiv hl. m. Prahy, Praha.
} 
Události roku 1938 měly hluboký dopad na československou společnost. První náznaky ústupu od demokratických ideálů se v pomnichovském státě objevily velmi záhy. Ze spolků byly rušeny nejdříve odborové centrály, později v roce 1939 všechny židovské spolky (Laštovka et al., 1998). Spolek Čsl. Liga proti antisemitismu existoval až do závěru roku 1938, kdy byl dobrovolně rozpuštěn. Poslední číslo Věstníku spolku vyšlo v říjnu 1938, a to i s menším stránkovým rozsahem, než bylo obvyklé. Úředně byl zrušen v roce 1939, poslední předseda B. Vančura oznámil úřadům, že se spolek dobrovolně rozešel bez ustanovení valné hromady pro nedostatek prostředků. Oficiálním likvidátorem spolku byl zvolen Bohumil Vančura, letitý předseda Ligy. ${ }^{35}$ Spolková činnost po válce obnovena nebyla.

\section{Závěr}

Československá Liga proti antisemitismu představovala demokratický spolek, jehož prvotním účelem byl boj proti zhoubné ideologii antisemitismu. Pokusila se sjednotit na společných základních hodnotách velice heterogenní skupinu potenciálních stoupenců. Ideály, k nimž se představitelé Ligy hlásili, mohly překlenout rozdílné světonázory jednotlivých skupin. Liga se snažila být zastřešující organizací v boji proti barbarství, jež spatřovala právě v antisemitismu. Antisemitismus byl $\mathrm{v}$ chápání členů Ligy daleko šířeji vymezeným pojmem, představoval útok na samotný základ demokratických hodnot. Nechápali antisemitismus jako problém židovský, ale celospolečenský, odmítali antisemitskou ideologii na základě univerzálně platného humanismu a na základě křest’ansko-židovské etiky. Právě nadstranickost, jistá nevyhraněnost a silný vliv křest'anství stály možná za skutečností, že Čsl. liga proti antisemitismu nenaplnila své očekávání. Neměla jednoduchou pozici mezi ostatními židovskými spolky ani mezi většinovou společností, která se ve druhé polovině 30 . let ocitla pod tlakem antisemitských stereotypů přicházejících zejména ze zahraničí, ale i domácí provenience. Členy nebyli jen Židé, naopak se zaměřila spíše na získávání nežidovských stoupenců, aby rozšiřovala řady bojovníků proti antisemitismu. Ve svém zápase se musela na rozdíl od svých protivníků spoléhat výhradně na demokratické prostř̌edky - nejdůležitější z nich, jímž se snažila vyvrátit řadu předsudků, dezinformací a lživých informací, představovala zejména osvěta. Vzděláváním společnosti prostřednictvím přednášek a tištěných materiálů poukazovala na existenci humanistických ideálů, které by měly být společné pro všechna náboženská, společenská i politická uskupení. Šírením humanistických myšlenek a etických hodnot realizovala svůj zápas s agresivní antisemitskou ideologií. Křest'anské ideály se nacházely paradoxně na straně bojovníků proti antisemitismu, i na straně jejich protivníků. Stěžejní osvětová činnost spolku byla nejvíce limitována finančními možnostmi Ligy. Tiskový fond nedosahoval potřebné výše, aby se za dobu existence Ligy vydaly více než dvě významnější publikace. Bohužel po roce 1938 již její existence pozbývala smyslu, nebot' společnost byla radikalizována i prostřednictvím politických špiček, jejichž prvořadým zájmem bylo vycházet vstříc německému sousedovi a pozvolna přijímat opatření a zákony platné ve třetí říši. Finanční hledisko nejspíše nepředstavovalo jediný důvod

\footnotetext{
${ }_{35}$ Československá liga proti antisemitismu. Spolkový katastr. Karton 965, sign. XXII/2028. Archiv hl. m. Prahy, Praha.
} 
pro rozpuštění Ligy proti antisemitismu, svou roli zajisté hrála i celospolečenská atmosféra, v níž se postupně začala prosazovat antisemitská politika. Je zarážející, že dnes, několik desetiletí po druhé světové válce, ve společnosti přetrvává potřeba organizace podobného zaměření, nebot' Liga proti antisemitismu byla založena roku 2007 Věrou Tydlitátovou za účelem monitoringu veškerých antisemitských a rasistických projevů.

\section{Seznam použitých zdrojů a literatury}

\section{Archivní prameny}

ČAPP. Karton 15a, inv.č. 832_2, Karton 16, Archiv Přemysla Pittra a Olgy Fierzové, Praha.

Československá liga proti antisemitismu. Spolkový katastr. Karton 965, sign. XXII/2028. Archiv hlavního města Prahy, Praha.

Fond Deutsches Casino- Deutsches Haus. Spolkový katastr. Karton 35, inv. číslo 634. Archiv hlavního města Prahy, Praha.

Fond Velkolóže pro Československý stát X. nezávislého řádu B'nai B'rith. Karton č. 13, inv. č. 46. Národní archiv, Praha.

Fond Zemský úřad Praha - spolkové záležitosti. Karton 984, signatura 19a-3247-33. Národní archiv, Praha.

Fond Zemský úřad Praha - spolkové záležitosti. Karton 1142, signatura 19-3297-1933. Národní archiv, Praha.

\section{Sbírky zákonů}

Zákon č. 121/1920 Sb., kterým se uvozuje ústavní listina Československé republiky. In: Sbírka zákonů a nařizení státu Československého, 6. 3. 1920, částka 26.

Zákon č. 508/1921 Sb., Smlouva mezi čelnými mocnostmi spojenými i sdruženými a Československem, podepsaná v Saint-Germain-en-Laye dne 10. zárí 1919. In: Sbirka zákonů a nařizeni státu Československého, 31. 12. 1921, částka 134.

\section{Periodika}

Věstník Čsl. Ligy proti antisemitismu, 1936-1938. Praha: Nákl. Čsl. Liga proti antisemitismu. Štít národa, 1920-1921. Praha: Slovanská strana protižidovská.

Sbratření, Měsičník k obrodě ducha a společnosti, 1931, 1935. Praha: Nákl. vlastním, redig. Přemysl Pitter.

\section{Internetové zdroje}

Archives Licra, 2018 [online]. [cit. 2018-09-14]. Dostupné z: http://archives.licra.org/category/histoire/histoire-1936-1944.

B'nai B'rith, 2018 [online]. Praha [cit. 2018-11-25]. Dostupné z: https://www.bnaibrith.org/. Holocaust, 2018 [online]. [cit. 2018-09-14]. Dostupné z: https://www.holocaust.cz/databazeobeti/obet/127127-samuel-steinherz/. 
Jednota bratrská - Historie pražského sboru, 2018 [online]. [cit. 2018-11-25]. Dostupné z: http://www.jednotabratrska.cz/praha/dokumenty/historie_prazskeho_sboru.pdf.

Jednota bratrská, (C) 2018 [online]. [cit. 2018-09-15]. Dostupné z: http://www.jbcr.cz/index.php/jbpovalcecechy/353-vaclav-vancura.

Le procès Schwartzbard - Naissance d'un combat, 26 octobre 1927, 2018 [online]. [cit. 201809-15]. Dostupné z: http://archives.licra.org/26-octobre-1927-le-proces-schwartzbardnaissance-dun-combat.

LICRA Jeunes info, Septembre 2005, 2018 [online]. [cit. 2018-09-10]. Dostupné $\mathrm{z}$ : http://licrachalons.free.fr/2005-09-09_licra_jeunes_n_5.pdf.

Ligue Internationale Contre le Racisme et l'Antisémitisme, 2018 [online]. [cit. 2018-09-10]. Dostupné z: http://www.licra.org/qui-sommes-nous.

\section{Literatura}

BĚLINA, Pavel et al., 1995. Dějiny zemí Koruny české II. Praha: Paseka. ISBN 80-85192-306.

ČAPKOVÁ, Kateřina, 2013. Češi, Němci, Židé? Národní identita Židi̊ v Čechách 1918 až 1938. Praha-Litomyšl: Paseka. ISBN 978-80-7432-294-5.

ČERMÁKOVÁ, Radka, 2003. Československá republika - nový stát ve střední Evropě a Židé. In: POJAR, Miloš, SOUKUPOVÁ, Blanka, ZAHRADNÍKOVÁ, Marie. Židovská menšina v Československu ve dvacátých letech. Praha: Židovské muzeum, s. 9-21. ISBN 8085608-72-3.

DOUBRAVA, Fedor, 1921. Tragédie Slovanstva a Francie. Praha: nák1. vl.

FRANKL, Michal a SZABÓ, Miloslav, 2015. Budování státu bez antisemitismu? Násilí, diskurz loajality a vznik Československa. Praha: Nakladatelství Lidové noviny. ISBN 978-807422-422-5

FRIEDMANN, František, 1937. Židé a židovství v životě a díle T. G. Masaryka, Praha: s.n. HAHN, Arnold, 1936. Před zraky národů, Proč umřel Stefan Lux? Jeho život, čin a poslední dopisy. Praha: nákladem ČSL. Ligy proti antisemitismu.

KÁRNÍK, Zdeněk, 2003. České země v ére první republiky (1918-1938), díl třetí, o přežití a o život (1936-1938). Praha: Libri. ISBN 80-7277-119-1.

KOROLIV, Vasilij, 1919. Ukrajinský národní hrdina Simon Petljura. Praha: Nákladem ukrajinského vyd. Družstva „Čas“.

KRÁlOVÁ, Kateřina, KUBÁTOVÁ, Hana, 2016. Návraty, poválečná rekonstrukce židovských komunit vzemích středovýchodní, jihovýchodní a východni Evropy. Praha: Karolinum. ISBN 978-80-246-3271-1

KŘESŤAN, Jiří, BLODIGOVÁ, Alexandra, BUBENÍK, Jaroslav, 2001. Židovské spolky $v$ českých zemích v letech 1918-1948. Praha: Institut Terezínské iniciativy. ISBN 80-8592427-7.

LAŠŤOVKA, Marek et al., 1998. Pražské spolky, soupis pražských spolků na základě úředních evidencí z let 1895-1990. Praha: Scriptorium. ISBN 80-902151-9-X. 
LICHTWITZ, Hans, 1937. Dějiny cionistického hnutí. Praha: Nákladem Židovského národního fondu, Ústřední svaz cionistický v ČSR. MATĚJČEK, Petr, 2017. Pittrova ,akce zámky“ jako klíčové období v životě Jehudy Bacona. In: Jsem Jehuda Bacon. Praha: Národní pedagogické muzeum. ISBN 978-80-86935-36-2.

NILUS, Sergej Alexandrovič, 1926. Protokoly ze shromáždění sionských mudrců. Praha: F. Komrska.

PĚKNÝ, Tomáš, 2001. Historie Židů v Čechách a na Moravě. Praha: Sefer. ISBN 80900895-4-2.

PETRÁŠ, René, 2009. Menšiny v meziválečném Československu: právní postavení národnostních menšin v první Československé republice a jejich mezinárodní ochrana. Praha: Karolinum. ISBN 978-80-246-1639-1.

Proč byla založena Slovanská strana protižidovská v Praze? Pro blaho a spásu národa českého, 1921. Praha: Nákladem Slovan. Strany protižidovské v Praze.

RÁDL, Emanuel, 1918. Rassové theorie a národ. Praha: Nakladatel B. Kočí.

ROHLING, August, 1876. Židé podle Talmudu, na uváženou křest'anům a židưm všech stavů. Praha: Nakladatel Theodor Mourek.

Sčitání lidu v republice Československé ze dne 1. prosince 1930, Díl I., 1934. Praha: Státní úr̆ad statistický.

SEDLÁČKOVÁ, Blanka, 1994. Pedagogická činnost Přemysla Pittera. In: Přemysl Pitter, Život a dílo, sborník referátů. Praha: Ped. Muzeum J. A. Komenského, Milidu, s. 45-49. ISBN 80-901461-1-2. 